\title{
Nexus between Production Input and Price Commodity: An Integration Analysis of Rice Barns in East Java of Indonesia*
}

\author{
Dwi WULANDARI ${ }^{1}$, Bagus Shandy NARMADITYA ${ }^{2}$, Putra Hilmi PRAYITNOª \\ Suryati ISHAK ${ }^{4}$, Sheerad SAHID $^{5}$, Lutfi Asnan QODRI ${ }^{6}$
}

Received: July 16, 2020 Revised: August 23, 2020 Accepted: August 28, 2020

\begin{abstract}
This study aims to examine the causality between production input and the price of rice in East Java, Indonesia. This study applied a quantitative method to understand in a comprehensive way the correlation between variables. The data used for this study were collected from several sources, including East Java Agriculture Office, Siskaperbapo.com, and Statistics Indonesia (BPS) of East Java. This research was carried out over five years, starting from 2014 to 2018. Furthermore, the data were analyzed using the Vector Error Correction Model (VECM) by employing E-Views (version 7). The findings of this study indicated that, in the long run, the population, rice production, and changes in people's income have a positive effect on price stability, but are inversely proportional if seen in the short term. In comparison, in the long run, farmer exchange rates variable has a negative impact on price stability, and inversely proportional in the short term, which has a positive effect. There are different implications when the people's income increases and the rice price declines; these have great potential to alleviate poverty in East Java, Indonesia. This is due to the fact that the price stability also concerns the welfare of the community.
\end{abstract}

Keywords: Production Input, Price Commodity, Rice Barns, Population Growth

JEL Classification Code: L11, Q02, Q21, R23

\section{Introduction}

Managing food price stability has been a challenge for governments both in developed and emerging countries. The

\footnotetext{
*Acknowledgements:

This research was funded through a grant by the Directorate of Research and Community Services (LPPM) Universitas Negeri Malang

${ }^{1}$ First Author and Corresponding Author. Faculty of Economics, Universitas Negeri Malang, Indonesia [Postal Address: Jalan Semarang 5 Malang, East Java, 65145, Indonesia]

Email: dwi.wulandari.fe@um.ac.id

${ }^{2}$ Faculty of Economics, Universitas Negeri Malang, Indonesia.

Email: bagus.shandy.fe@um.ac.id

${ }^{3}$ Faculty of Education, Universiti Kebangsaan Malaysia, Malaysia. Email: putra.hilmi.fe@um.ac.id

${ }^{4}$ Faculty of Economics and Management, Universiti Putra Malaysia, Malaysia. Email: suryatiis@upm.edu.my

${ }^{5}$ Faculty of Education, Universiti Kebangsaan Malaysia, Malaysia. Email: sheerad@ukm.edu.my

${ }^{6}$ Faculty of Economics, Universitas Negeri Malang, Indonesia.

Email: lutfiasnan@yahoo.co.id

(c) Copyright: The Author(s)

This is an Open Access article distributed under the terms of the Creative Commons Attribution Non-Commercial License (https://creativecommons.org/licenses/by-nc/4.0/) which permits unrestricted non-commercial use, distribution, and reproduction in any medium, provided the original work is properly cited.
}

fundamental rationale is that the food price directly affects the household welfare (Dawe \& Maltsoglou, 2014). In his preliminary studies, Timmer (2014) believes that essential commodities for households, such as grains and rice have experienced a significant rise in prices. The increase was around 60 percent and almost occurred in all parts of the world. The escalating population potentially brings as a consequence a condition of shortage (Chattopadhyay \& Mitra, 2018).

Several facts show the differences in the approach to controlling food prices in developed and developing countries (Bellemare, 2015; Furceri et al., 2018). For instance, Furceri et al. (2018) pointed out that the consumption pattern in a region or nation will determine rice demand. Therefore, agricultural and weather conditions are two crucial factors driving the availability of the rice commodity (Hansen, 2019). Another factor that can also impact on the stability of rice's price is taxes and subsidies from the government (Anderson \& Nelgen, 2012).

In the context of Indonesia, rice is the primary staple product, and it provides a crucial element for the community welfare. Approximately 250 million Indonesian consume rice every day and is in need to be fulfilled (Silalahi et al., 2019; 
Hermawan \& Maipita, 2017). The increase in population and the demand for the main commodity drive the fluctuation of the availability and prices of goods. Additionally, rice contributes to food security, fighting poverty, macroeconomic stability, and the country's economic growth (Sayeed \& Yunus, 2018). For this matter, the rice price should be managed and secured by the government to provide food price stability for the whole community (Mariyono, 2018).

Both the central and regional governments are obliged to control food price stability and to maintain the availability of staples. Besides, the quality control of food commodities must be guaranteed so the commodity has good quality at affordable prices for the community. In this case, the purpose of controlling the stability of rice prices is to avoid the community's turmoil regarding basic needs. According to Qodri et al. (2020), food price fluctuations are normal as long as there are within reasonable limits. This reflects a conducive and competitive market situation.

Food commodities, particularly rice, are increasingly expensive and are predicted to lead to fluctuations that can be risky for consumers, producers, and the government (Mustafa \& Sivarajasingham, 2019). The fluctuations from the calculation of a price that does not reflect a market performance will lead to mistakes in policymaking by the government as the regulator. In this case, all are affected by the uncontrolled price of rice. It can be concluded that rice commodities affect people's livelihood nationally.

According to Indonesia Statistics (BPS, 2020), East Java province had a population of 39.89 million in 2020 . A vast population will be affected by the availability of existing commodities, particularly rice. In this case, the escalating population should also be assisted with economic growth to accomplish a stable rice price. The quality of life of the population that is stable and the progress of the economy in East Java will impact on the welfare and ease job creation (Purwanti et al., 2020). Because this is related to the level of income, it will have a high impact on people's welfare, especially the salaries of workers in East Java. Indeed, prior research conducted by Trisnowati and Budiwinarto (2013) showed that income positively influences the proportion of expenditure for rice with a considerable elasticity value.

Despite the studies on the volatility price commodity, however, scholars have overlooked the input price perspectives. Most studies are focused on the socio-economic factors (Wardis, 2014), climate change (Novianti et al., 2017; Caruso et al., 2016), technical efficiency (Mariyono, 2014), and trade liberalization (Istiqomah et al., 2005). For these reasons, the contribution of this study is twofold. First, this study contributes to the existing literature on food price volatility by examining the relationship between input price and rice price commodity. Second, the study focuses on Indonesia, particularly in East Java, which is unique due to the fact that this region has experienced the highest population growth and the most volatile of rice price.

\section{Literature Review}

The agricultural sector plays a crucial role for the economy of a nation, particularly in the developing countries (Nguyen et al., 2020; Ridha et al., 2017). Therefore, when the factors causing the economic shocks are sourced from within the country, they will cause fluctuations in commodity prices on the domestic market. For example, when crop failure occurs due to weather conditions or natural disasters commodity prices fluctuate and structural inflation is stimulated.

The acquaintance with structural inflation, a structural obstacle and gap in developing countries, is called structural bottlenecks (Raissi \& Tulin, 2018; Policar et al., 2019). In this case, structural bottlenecks can occur in three cases (Kamann et al., 2019; Crescimanno et al., 2014). First, inelastic supply of agriculture (food) sector. This is caused by the management system, especially in the agricultural sector, and the lack of use of renewable technology, which lead to the inadequacy of supply in the market. This condition has implications for the inability to compensate from the demand side.

Second, there is insufficient foreign exchange reserves caused by the value of exports compared to the value of imports in a country (Belke et al., 2013; Wong \& Huang, 2012). This problem will cause difficulty in the ability to import manufactured goods, primarily capital goods. Also, when the demonstration effect occurs, it will drive to consumption patterns. As a result, it has an implication on the shortage condition. Third, inadequate government spending has an impact on the pattern of budget deficits. Therefore, it has the potential to swell foreign loans, which actually becomes a short-term solution.

According to Garnett (2014), food commodities have a crucial role for the sustainability of human life. Besides, food is the most basic requirement whose availability must be guaranteed. With food availability, the community will find food easily and meet its needs. That way, the community feels prosperous. Additionally, food supply must also be supported by the affordability of the selling price, this is related to how the community economy is positioned (Cudjoe et al., 2010).

The growing body of literature has examined the factors affecting food prices volatility. Blein and Longo (2009); Nicoleta et al. (2013) remarked that the price volatility is caused by the climate and air quality in an area, the absence of producer organizations (farmers) in the marketing chain, and the market integration. Furthermore, Gotz et al. (2013) concluded that price fluctuations are influenced by supply and demand in the market. As for agricultural commodities, input and fuel markets are the main causes of market nutrient 
fluctuations. On the other hand, supply availability can also trigger price increases.

Agricultural commodities are perishable goods and require large space (bulkyness), so shorter chain management should be provided (Bosona \& Gebresenbet, 2013). In fact, many farmers complained because they obtain a small revenue and it was the middlemen who were free to play the price and receive a bigger profit. A longer average distribution circuit can cause a decrease in product quality and the more severe the loss of quality, the more expensive the goods become (Wulandari et al., 2017).

\section{Research Methods and Materials}

This study applied a quantitative method to understand the correlation between variables. Data used for this study were collected from East Java Agriculture Office, Siskaperbapo. com, and Statistics Indonesia (BPS) of East Java province. The research was carried out over five years, from 2014 to 2018. The data to be analyzed are monthly data so they were accumulated over 60 months. Furthermore, the data were analyzed using the Vector Error Correction Model (VECM) employing E-Views (version 7). The focus on East Java of Indonesia is unique due to the fact that East Java is one of the national food barns, especially commodities related to rice, but where rice commodity price often experiences fluctuations during the period. In more detail, the variables of the study are provided in Table 1.

The variables in this study are the price of rice (HB), total population (JP), volume of rice production (JPB), average income (RRP), and farmer exchange rate (NTP). This data processing uses the E-Views (version 7.0). Following are the specifications of the VECM model:

$$
\Delta \mathrm{yt}=\mu 0 \mathrm{x}+\mu 1 \mathrm{xt}+\Pi \mathrm{xyt}-1+\Sigma \mathrm{ik} \Delta \mathrm{yt}-1+\varepsilon \mathrm{t}
$$

yt $=$ Vector containing variables analyzed in research

$\mu 0 \mathrm{x}=$ Intercept Vector

$\mu 1 \mathrm{x}=$ Regression Coefficient Vector

$\mathrm{t} \quad=$ Time Trend

$\Pi \mathrm{x}=\alpha \times \beta^{\prime}$, where $\mathrm{b}^{\prime}$ consists long-term cointegration equation yt-1 = Variable in level

Гik $=$ Regression coefficient matrix

$\mathrm{k}-1=$ Ordo VECM from VAR

et $\quad=$ Error term

VECM modeling based on the variables used is as follows:

$$
\begin{array}{r}
\Delta H B=a+\sum_{i=1}^{n} \beta i \Delta H B_{t-i}+\sum_{i=1}^{n} \beta i \Delta J P_{t-i}+\sum_{i=1}^{n} \beta i \Delta J P B_{t-i}+ \\
\sum_{i=1}^{n} \beta i \Delta N R R P_{t-i}+\sum_{i=1}^{n} \beta i \Delta N T P_{t-i}+\lambda E C_{t-1}+\varepsilon_{t}
\end{array}
$$

It has the meaning that a 0 is a constant, $t$ is a deterministic trend, is the error term. If the autoregressive of $\left.\mathrm{Y}_{(\mathrm{Y}}(\mathrm{t}-1)\right)$ contains a unit root (unit root), then the ratio $t$ ( $t$ ratio) for a 1 should be consistent with the hypothesis a_ $1=0$.

$$
\begin{aligned}
& \lambda_{\text {Trace }}(r)=-T \sum_{i=r+1}^{g} \operatorname{in}\left(1-\lambda_{i}\right) \\
& \lambda_{\text {Max }}(r, r+1)=-T \operatorname{In}\left(1-\lambda_{r+1}\right)
\end{aligned}
$$

$\lambda \_i$ is estimated with ordered eigenvalue. The standard approach for Johansen's is maximum likelihood. First, estimating Trace and Maximum Eigenvalue statistics, then comparing the appropriate critical values. In this cointegration test, if there is a cointegration between variables or the rank of cointegration is higher than zero, the Vector Error Correction Model can be conducted.

\section{Results and Discussion}

The study uses the Augmented Dicky Fuller Test and employs a critical value of 5 percent. If the value of t-ADF is smaller than the Mackinnon value, it can be interpreted that the data tested are stationary and do not contain unit roots.

Table 2 provides information about the result of stationary test data using ADF test. Based on the data in the table, it can be concluded that all variables are stationary in the first different with different degree of coefficient value. Precisely, rice price and rice production variables have coefficient value of 0.0001 .

Table 1: Variables and secondary data sources

\begin{tabular}{|l|c|c|c|}
\hline No & Variable & Symbol & Source \\
\hline 1 & Rice price & HB & Siskaperbapo.com \\
\hline 2 & Total Population & JP & BPS East Java \\
\hline 3 & Rice production & JPB & BPS East Java \\
\hline 4 & Income average & RRP & BPS East Java \\
\hline 5 & Farmer exchange rates & \\
\hline
\end{tabular}


As for the variable number of the population is stationary at First Different degrees with a coefficient of 0.0000 . Lastly, variable average revenue and farmer exchange rate have coefficient value of 0.0001 and 0.350 , respectively. According to Firdaus (2011), the function of the optimal lag

Table 2: Data Stationary Test Results with the ADF Test

\begin{tabular}{|l|l|c|}
\hline Variable & \multicolumn{1}{|c|}{ Decision } & $\begin{array}{c}\text { Coefficient } \\
\text { Value }\end{array}$ \\
\hline HB & Stationer in the First Different & 0.0001 \\
\hline JPB & Stationer in the First Different & 0.0001 \\
\hline JP & Stationer in the First Different & 0.0000 \\
\hline RRP & Stationer in the First Different & 0.0001 \\
\hline NTP & Stationer in the First Different & 0.3500 \\
\hline
\end{tabular}

Note: HB (rice price); JPB (rice production); JP (number of population) test aims to address the autocorrelation problem in a VAR. It also plays role as an indicator of how long one variable reacting with other variables. In this study, the lag test applied the Schwarz Information Criterion (SIC) method. Based on the results of the lag test it can be concluded that for the commodity the price of rice is at first Lag, the price of granulated sugar and the price of cooking oil are at second Lag (see Table 3).

After the optimum lag test, the cointegration test is then performed. The purpose of the cointegration test is to determine whether groups of variables that are not stationary at the level of level still meet the requirements of the integration process; we also use the Johansen trace statistics test cointegration test method. In cointegration tests, the most important thing is about testing criteria based on trace statistics. If the value of the trace statistic is greater than the critical value of 5 percent, then the alternative hypothesis is accepted. The cointegration test results of the rice price are provided in Table 4.

Table 3: The Optimum Lag Test (Price of Rice)

\begin{tabular}{|l|c|c|c|c|c|c|}
\hline Lag & LogL & LR & FPE & AIC & SC & HQ \\
\hline 0 & -209.9624 & NA & 0.001708 & 7.816814 & 7.999299 & 7.887383 \\
\hline 1 & -47.78830 & 288.9647 & $1.17 \mathrm{e}-05^{*}$ & 2.828666 & $3.923575^{*}$ & $3.252076^{*}$ \\
\hline 2 & -23.33959 & 39.11794 & $1.22 \mathrm{e}-05$ & 2.848712 & 4.856046 & 3.624964 \\
\hline 3 & -2.188594 & 29.99596 & $1.49 \mathrm{e}-05$ & 2.988676 & 5.908433 & 4.117770 \\
\hline 4 & 17.03721 & 23.77008 & $2.07 \mathrm{e}-05$ & 3.198647 & 7.030829 & 4.680583 \\
\hline 5 & 58.91425 & $44.16124^{*}$ & $1.37 \mathrm{e}-05$ & $2.584936^{*}$ & 7.329542 & 4.419714 \\
\hline
\end{tabular}

Table 4: Unrestricted Cointegration Rank Test (Trace)

\begin{tabular}{|c|c|c|c|c|}
\hline Hypothesized & & Trace & 0.05 & \\
\hline No. of CE(s) & Eigenvalue & Statistic & Critical Value & Prob.** \\
\hline None * & 0.557162 & 90.30058 & 69.81889 & 0.0005 \\
\hline At most 1 & 0.290397 & 43.87118 & 47.85613 & 0.1127 \\
\hline At most 2 & 0.235452 & 24.31732 & 29.79707 & 0.1874 \\
\hline At most 3 & 0.121542 & 9.014514 & 15.49471 & 0.3640 \\
\hline At most 4 & 0.028158 & 1.628036 & 3.841466 & 0.2020 \\
\hline \multicolumn{5}{|c|}{ Unrestricted Cointegration Rank Test (Maximum Eigenvalue) } \\
\hline Hypothesized & & Max-Eigen & 0.05 & \\
\hline No. of CE(s) & Eigenvalue & Statistic & Critical Value & Prob.** \\
\hline None * & 0.557162 & 46.42940 & 33.87687 & 0.0010 \\
\hline At most 1 & 0.290397 & 19.55386 & 27.58434 & 0.3729 \\
\hline At most 2 & 0.235452 & 15.30281 & 21.13162 & 0.2682 \\
\hline At most 3 & 0.121542 & 7.386477 & 14.26460 & 0.4445 \\
\hline At most 4 & 0.028158 & 1.628036 & 3.841466 & 0.2020 \\
\hline
\end{tabular}


Based on Table 4, it can be seen that the value of the trace test shows the existence of one equation that co-integrated with each other. The value of the max eigenvalue test also shows there is one cointegrated equation. Therefore, the variable rice price can be found in a long-term relationship. From the variables that have been tested, cointegration indicates the existence of a long-term relationship between the estimated variables, so that the VAR model can be combined with ECM into VECM. From the results of the analysis using the Vector Error Correction Model (VECM), we see the relationship in the long term and also in the short term between the prices of rice (HB), granulated sugar (HGP), cooking oil (HMG), total population (JP), total production (JPB), average income (RRP), and farmer exchange rate (NTP). Following is the analysis using the VECM model (see Table 5).

The Vector Error Correction Model analysis results in rice prices' short-term conditions have a positive effect on the critical value of five percent of 0.314 . This implies that, in the short term, if there is a 1 percent increase in rice price in the previous month, it will raise the price of rice by 0.314 percent in the current month. This result is in accordance with a preliminary study by Sugiyanto and Hadiwigeno (2012), which remarked that East Java province operates as a rice barn at an affordable price. This situation affects the rice suppliers that sell this commodity to other provinces, potentially leading to the shortage in East Java.

The coefficient of total population (JP) is $-1,049$ and influential, but not significant, meaning that an increase in population (JP) of 1 percent in the previous month will reduce the price of rice by $-1,049$ percent in the current

Table 5: VECM Test of Rice Price

\begin{tabular}{|l|c|c|}
\hline \multirow{2}{*}{ Variable } & \multicolumn{2}{|c|}{ The rice price } \\
\cline { 2 - 3 } & Coefficient & t-statistics \\
\hline CointEq1 & 0.03 & 3.22 \\
\hline Short term & & \\
\hline D(HB(-1)) & 0.31 & 2.28 \\
\hline D(JP2(-1)) & -1.04 & -0.91 \\
\hline D(JPB2(-1)) & -0.07 & -3.08 \\
\hline D(RRP2(-1)) & -0.06 & -0.08 \\
\hline D(NTP(-1)) & 0.14 & 3.82 \\
\hline Long term & & \\
\hline JP2(-1) & 40.95 & 12.22 \\
\hline JPB2(-1) & 2.59 & 6.49 \\
\hline RRP2(-1) & 0.30 & 0.44 \\
\hline NTP(-1) & -0.35 & -0.92 \\
\hline
\end{tabular}

Note: significant level of $5 \%=2.0$ month. The factor of East Java province, one of the national rice suppliers, has controlled rice availability, especially in East Java. On the other hand, population growth factors must also be a particular concern, especially in terms of community productivity.

This finding is in line with a prior study by Aryati (2001), which states that the total population does not significantly influence rice prices in East Java in the short term. The fundamental rationale is that rice barns in East Java remain adequate in the short term to meet market needs or demands. According to Syaifullah (2013), even with the creation of the province of East Java as one of the national rice barns, rice commodities are often distributed to other provinces such as Central Java and West Java provinces. Besides, rice is one of the primary staple elements and has a very strategic value. Prasada et al. (2018) stated that rice is one of the main pillars in the movement of the economic control system in East Java, one of the national rice barns.

Rice commodity is the primary commodity even though the income of the community has increased or will still not be sought after. This is because there has not been a substitute item from rice that is strong enough to replace rice as the primary food commodity. However, the price of rice must remain conditioned at all costs; price stability is the main policy that must be done by the government through price intervention. Gouel and Jean (2013) research policies taken by developing countries to stabilize the price of food commodities, one of which is to maintain food production availability. Likewise, the variable of rice production (JPB) has a negative and significant effect, with a coefficient of -0.07 percent. This implies that, if rice production increases by 1 percent in the previous month, it will reduce rice prices by -0.07 percent in the current month. This is quite positive for the sustainability of people's welfare. On the other hand, a positive trend must be maintained by making a proper irrigation channel to support increased production.

This finding agrees with a study by Wibowo et al. (2015) that the higher level of production of rice commodities will reduce the price level in the community so that it becomes affordable. According to Dawe and Timmer (2012), rice production is a determining factor of rice price stability. This aspect of the amount of production influences the availability of rice commodity itself. The availability of rice depends on high volumes of production, especially the rice produced within the province of East Java itself. However, in recent years, the availability of rice commodities has increased the amount of production. Qodri et al. (2020) state that the amount of rice production must be maintained, especially the arrival of imported rice, which can affect the condition of local rice. This is quite basic, considering that rice is a primary commodity. According to research conducted by Pudaka et al. (2018), rice production affects the productivity of rice commodities, both provincial and national scale. 
RRP's variable also had an insignificant negative effect of -0.06 , meaning that when the average income increased by 1 percent in the previous month, the price of rice would decrease by 0.06 percent in the current month. This is because the nature of rice commodities, which are stapled goods, does not cause people to switch to substitute goods despite rising prices. This illustrates that in the short term, community income does not affect rice prices in East Java. According to Makbul et al. (2014), because there is no substitute for rice, the elasticity of rice price response to income tends to be small. On the other hand, according to Arianti et al. (2000), the elasticity figure of domestic rice commodities of -0.35 can be interpreted as each increase in rice will reduce the level of rice consumption in the aggregate. The implication is that rice prices' stability is needed considering the national dependency rate of the community is still 97 percent.

Meanwhile, farmer exchange rates (NTP) have a positive and significant effect with a coefficient of 0.14 , which means that an increase of 1 percent in the previous month will raise rice price by 0.14 percent in the current month. This can be attributed to the high demand for rice in proportion to the production factors needed by farmers so that farmers' expenditures are also higher. NTP has experienced a fluctuation during the period. The lowest point is in AprilMay, the harvest season. This condition impacts on the increase in farmer production. It cannot be interpreted as an indicator of increasing FTT because its measurement is solely based on the ratio of selling prices.

According to research conducted by Nurasa and Rachmat (2013), NTP has a positive and significant influence, especially in lean months, from December to January. Indeed, Nirmala et al. (2016) stated that farmer exchange rates significantly influence rice commodities' prices. In the long run, the population (JP) variable has a significant positive effect. When the JP experiences an increase of 1 percent, it will increase rice prices by 40.1 percent. This is in line with Milani et al. (2017), which revealed that the principle of demand when the number of residents needs staple foods will increase, making selling prices go up. Even though it is said to be a food granary, the availability of rice in East Java cannot be said to be guaranteed for its long-term availability.

Increasing the population can be used as an illustration to see the economic growth of the surrounding community because it could be that, with the increase of population productivity, income can go up. That way, each family's burden level decreases, and the quality of life increases thanks to more productive economic activities. With the increase in population every year, agricultural land, especially rice, actually decreases. This is caused by the construction of buildings and housing, which mostly sacrifice agricultural land without government policies. Transformation of agricultural lands into built-up areas is rife, which can have implications for decreasing the amount of rice production.

The population is one of the elements that are the basis for making a regional policy (Prawoto \& Cahyani, 2020). This means that a large population such as East Java requires a unique approach in making policy; in this case, it is related to rice price control, a basic need of the people of East Java. One of the policies is to ensure that the availability remains under control, as Timmer (2011) argues. The best solution to deal with price fluctuations is to maximize stock.

Variable Number of Rice Production (JPB), in the long run, has a significant positive effect with a coefficient of 2.59 percent, which means that when the JPB increases by 1 percent, it will raise the price by 2.59 percent. This is due to a large population and the high level of consumption of the people of East Java in rice commodity, causing rice prices to continue to rise despite the increase in production. Most rice production takes place in the first half of every year because these are harvest months. That way, prices are expected to be stable and the staple remains affordable.

The data based on the Consumer Price Index for rice commodities have experienced an upward trend from 2011 to 2018. Based on these data, the demand for rice continues to increase, which affects the rise in price. According to Muthayya et al. (2014), the level of public consumption has a positive and significant influence on national rice prices. The population of East Java has much impact on the demand for consumption of rice prices.

Determining the price of rice must be made with caution. This is reasonable because rice is a major commodity for the people of East Java and even Indonesia. This finding is also supported by Wibowo et al. (2015), who stated that the determination of the price of rice is caused by the amount of production by the farmers. On the other hand, most agricultural locations are in rural environments that are located very far from cities and economic infrastructure development.

Meanwhile, the average revenue (RRP) variable also has an insignificant positive effect, with a coefficient value of 0.30 percent. When RRP increases 1 percent, it will increase the price of rice by 0.30 percent. This means that when people's income rises, it will increase rice prices in East Java. This usually happens especially in the East Java region when approaching the feast and the time of Ramadan. When approaching Ramadan, people's income rises due to the holiday allowance. At that time, the prices of staples tended to increase. Therefore, the government also encourages a low-cost market to ensure that the prices of essential commodities remain affordable.

According to Septiadi and Joka (2019), income factors can positively influence rice prices in the long run. The primary goods demand factor is caused by the people of East Java who must continue to buy rice for their daily needs. 
According to McCulloch (2008), the poor tend to depend on rice rather than other commodities. That way, the price of rice is not a reference for the community when buying it. Rising community incomes and falling rice prices have great potential to reduce poverty in East Java. Because this also concerns the welfare of the community. With controlled prices and rising public incomes, it is expected that the price of rice commodities can be affordable, and poverty is also expected to fall. In this way, rice price stability must primarily be controlled by the regional and provincial governments.

In contrast, the Farmer Exchange Rate variable (NTP) has an insignificant negative effect with a coefficient of -0.35 percent, which means that when Farmer Exchange Rate Rises by 1 percent, it will reduce the price of rice by -0.35 percent. Data of Farmer Exchange Rates in 2014-2017 are in the range of 104.7. This means that it is lower than the average NTP in 2018, which was 106.7. Various policies issued by the government regarding low rice prices have also become confusing. At the same time, farmers hope that their income rises, and the community wants rice prices to remain affordable.

Malian et al. (2016) remarked that, where this relates to affordable rice price policies that harm farmers and are unable to encourage the industrial sector to compete on the world stage, imported rice is also a significant problem for the sustainability of farmers' welfare. The current government policy does not favor farmers' welfare. This can be seen from the import policy that is facilitated and can threaten the sustainability of local rice production, the elimination of fertilizer subsidies, the technology of farmers who are still said to be lagging far behind. Farmer Exchange Rate (NTP) must always be improved because it is related to the design of farmers' welfare. Especially at the time of harvesting, the FTT tends to be low, whereas, in fact, at the end of the FTT, it is even higher.

\section{Conclusions}

The high level of population in East Java makes the pattern of public consumption affect the increase in prices, which has implications for the stability of rice prices, although this does not apply in the short term because availability is still said to be sufficient. The high growth in population and the shrinking of agricultural lands affect the stability of rice prices in East Java. This is also consistent with the amount of rice production that affects the stability of rice prices in the long run, but does not apply to the short term. Rice production at the highest level of production is at the beginning of the year when it is the harvest period. Also, community income, in this case, has a long-term positive effect, but does not apply in the short term. Rice is a commodity that does not have a substitution factor in East Java. At the same time, farmer exchange rates, in the long run, have a negative effect and inversely proportional in the short term, which has a positive effect. There are particular implications when the increase in people's income and the decline in the price of rice have great potential to reduce poverty in East Java.

\section{References}

Anderson, K., \& Nelgen, S. (2012). Trade barrier volatility and agricultural price stabilization. World Development, 40(1), $36-48$.

Aryati, K. D. (2001). Analysis of Factors Affecting Local Rice Demand in East Java 1991-1999. Doctoral dissertation, Universitas Airlangga, Indonesia.

Belke, A., Bordon, I. G., \& Volz, U. (2013). Effects of global liquidity on commodity and food prices. World Development, 44, 31-43.

Bellemare, M. F. (2015). Rising food prices, food price volatility, and social unrest. American Journal of Agricultural Economics, 97(1), 1-21.

Blein, R., \& Longo, R. (2009). Food price volatility - how to help smallholder farmers manage risk and uncertainty. Discussion paper prepared for the Round Table of 32nd session of IFAD's Governing Council (February, 18). Available at: http://www. ifad.org/events/gc/32/ roundtables/1.pdf

Bosona, T., \& Gebresenbet, G. (2013). Food traceability as an integral part of logistics management in food and agricultural supply chain. Food Control, 33(1), 32-48.

BPS. (2020). Jawa Timur in Figure 2020. Statistics of East Java Province

Caruso, R., Petrarca, I., \& Ricciuti, R. (2016). Climate change, rice crops, and violence: Evidence from Indonesia. Journal of Peace Research, 53(1), 66-83.

Chattopadhyay, M., \& Mitra, S. K. (2018). Comparative decision models for anticipating shortage of food grain production in India. Theoretical and Applied Climatology, 131(1-2), 523-530.

Crescimanno, M., Galati, A., \& Bal, T. (2014). The role of the economic crisis on the competitiveness of the agri-food sector in the main Mediterranean countries. Agricultural Economics, 60(2), 49-64.

Cudjoe, G., Breisinger, C., \& Diao, X. (2010). Local impacts of a global crisis: Food price transmission, consumer welfare and poverty in Ghana. Food Policy, 35(4), 294-302.

Dawe, D., \& Maltsoglou, I. (2014). Marketing margins and the welfare analysis of food price shocks. Food Policy, 46, 50-55.

Dawe, D., \& Timmer, C. P. (2012). Why stable food prices are a good thing: Lessons from stabilizing rice prices in Asia. Global Food Security, 1(2), 127-133.

Firdaus, M. (2011). Econometrics application for panel data and time series. Bogor, Indonesia: IPB Press.

Furceri, D., Loungani, P., \& Zdzienicka, A. (2018). The effects of monetary policy shocks on inequality. Journal of International Money and Finance, 85, 168-186. 
Garnett, T. (2014). Three perspectives on sustainable food security: efficiency, demand restraint, food system transformation. What role for life cycle assessment? Journal of Cleaner Production, 73, 10-18.

Gotz, L., Glauben, T., \& Brummer, B. (2013). Wheat export restrictions and domestic market effects in Russia and Ukraine during the food crisis. Food Policy, 38, 214-226.

Gouel, C., \& Jean, S. (2013). Optimal food price stabilization in a small open developing country. The World Bank Economic Review, 29(1), 72-101. https://doi.org/10.1093/wber/lht018

Hansen, G. E. (2019). Agricultural and rural development in Indonesia. London, UK: Routledge.

Hermawan, W., \& Maipita, I. (2017). Factors Affecting the Domestic Price of Rice in Indonesia. Jurnal Ekonomi dan Kebijakan, 10(1), 155-171.

Istiqomah., Zeller, M., \& von Cramon-Taubadel, S. (2005). Volatility and integration of rice markets in Java, Indonesia: A comparative Analysis before and after Trade Liberalization. In: Conference on International Agricultural Research for Development Stuttgart-Hohenheim.

Kamann, D. J. F., Alfaro, J. A., \& Sebrek, S. S. (2019). 28 years of traceability management: trends, bottlenecks and opportunities. International Journal of Procurement Management, 12(1), 56-87.

Makbul, Y., Ratnaningtyas, S., \& Dwiyantoro, P. (2014). Prices Cointegration Analysis between Rice and Paddy in Indonesia: A Preliminary Study. Journal of Business and Economics, 5(3), 390-396.

Malian, A. H., Mardianto, S., \& Ariani, M. (2016). Factors affecting rice production, consumption and prices and food inflation. Jurnal Agro Ekonomi, 22(2), 119-146

Mariyono, J. (2014). Rice production in Indonesia: policy and performance. Asia Pacific Journal of Public Administration, 36(2), 123-134.

Mariyono, J. (2018). Productivity growth of Indonesian rice production: sources and efforts to improve performance. International Journal of Productivity and Performance Management, 67(9), 1792-1815

McCulloch, N. (2008). Rice prices and poverty in Indonesia. Bulletin of Indonesian Economic Studies, 44(1), 45-64.

Milani, P., Carnahan, E., Kapoor, S., Ellison, C., Manus, C., Spohrer, R., \& Kreis, K. (2017). Social marketing of a fortified staple food at scale: generating demand for fortified rice in Brazil. Journal of Food Products Marketing, 23(8), 955-978.

Mustafa, A. M. M., \& Sivarajasingham, S. (2019). Dynamic linkages between food inflation and its volatility: evidence from Sri Lankan economy. Journal of Asian Finance, Economics and Business, 6(4), 139-145. https://doi.org/10.13106/jafeb.2019. vol6.no4.139

Muthayya, S., Sugimoto, J. D., Montgomery, S., \& Maberly, G. F. (2014). An overview of global rice production, supply, trade, and consumption. Annals of the New York Academy of Sciences, 1324(1), 7-14.

Nguyen, P.-H., Tsai, J.-F., Kumar G, V. A., \& Hu, Y.-C. (2020). Stock Investment of Agriculture Companies in the Vietnam Stock Exchange Market: An AHP Integrated with GRA-TOPSISMOORA Approaches. Journal of Asian Finance, Economics and Business, 7(7), 113-121. https://doi.org/10.13106/ jafeb.2020.vol7.no7.113

Nicoleta, L., Rovinaru, F., \& Rovinaru, M. (2013). Assessing the Price Risk on the Romanian Agricultural Market: Analyses and Implications. Interdisciplinary Management Research, 9, 469-479.

Nirmala, A. R., Hanani, N., \& Muhaimin, A. W. (2016). Analysis of Factors Affecting the Exchange Rate of Food Crop Farmers in Jombang. Habitat, 27(2), 66-71.

Novianti, T., Busnita, S. S., \& Oktaviani, R. (2017). How far climate change affects the Indonesian paddy production and rice price volatility? International Journal of Agricultural Sciences, 1(1), $1-11$.

Nurasa, T., \& Rachmat, M. (2016). Analysis of Response and Factors Affecting Indonesian Rice Demand. Jurnal Agro Ekonomi, 31(2), 60-179.

Policar, T., Schaefer, F. J., Panana, E., Meyer, S., Teerlinck, S., Toner, D., \& Żarski, D. (2019). Recent progress in European percid fish culture production technology-Tackling bottlenecks. Aquaculture International, 27(5), 1151-1174.

Prasada, I. Y., Dhamira, A., \& Nugroho, A. D. (2018). Supply Response of Paddy in East Java: Policy Implications to Increase Rice Production. AGRARIS: Journal of Agribusiness and Rural Development Research, 4(2), 129-138.

Prawoto, N., \& Cahyani, R. D. (2020). Analysis of Unequal Distribution of Population Income in Indonesia. Journal of Asian Finance, Economics and Business, 7(7), 489-495. https:// doi.org/10.13106/jafeb.2020.vol7.no7.489

Pudaka, D. L., Rusdarti, R., \& Prasetyo, P. E. (2018). Efficency analysis of rice production and farmers' income in Sengah Temila District Landak Regency. Journal of Economic Education, 7(1), 31-38.

Purwanti, P., Susilo, E., \& Indrayani, E. (2020). Business Empowerment Program and Household Economic Welfare: Lesson from Indonesia. Journal of Asian Finance, Economics, and Business, 7(1), 313-320. https://doi.org/10.13106/ jafeb.2020.vol7.no1.313

Qodri, L. A., Wulandari, D., \& Sumarsono, H. (2020). Food Stability Analysis in East Java. International Journal of Scientific \& Technology Research, 9(2), 3712-3716.

Raissi, M., \& Tulin, V. (2018). Price and income elasticity of Indian exports - The role of supply-side bottlenecks. The Quarterly Review of Economics and Finance, 68, 39-45.

Ridha, R. N., \& Wahyu, B. P. (2017). Entrepreneurship intention in agricultural sector of young generation in Indonesia. Asia Pacific Journal of Innovation and Entrepreneurship, 11(1), 76-89. https://doi.org/10.1108/APJIE-04-2017-022 
Sayeed, K. A., \& Yunus, M. M. (2018). Rice prices and growth, and poverty reduction in Bangladesh. Rome, Italy: FAO.

Septiadi, D., \& Joka, U. (2019). Analysis of Response and Factors Affecting Indonesian Rice Demand. Agrimor, 4(3), 42-44.

Silalahi, N. H., Yudha, R. O., Dwiyanti, E. I., Zulvianita, D., Feranti, S. N., \& Yustiana, Y. (2019). Government policy statements related to rice problems in Indonesia. 3BIO: Journal of Biological Science, Technology and Management, 1(1), $35-41$.

Sugiyanto, C., \& Hadiwigeno, S. (2012). Integration of the Indonesian Rice Market with the International Rice Market. Jurnal Ekonomi dan Kebijakan Pembangunan, 1(2), 79-103.

Syaifullah, Y. (2013). Food security and rice distribution patterns in East Java Province. JEJAK: Jurnal Ekonomi dan Kebijakan, 6(2), 103-111.

Timmer, C. P. (2014). Food Security in Asia and the Pacific: The Rapidly Changing Role of Rice. Asia \& the Pacific Policy Studies, 1(1), 73-90.

Timmer, P. (2011). Managing Price Volatility: Approaches at the global, national, and household levels. In: Stanford Symposium Series on Global Food Policy and Food Security in the 21st Century. Center on Food Security and the Environment, Stanford University.
Trisnowati, J., \& Budiwinarto, K. (2013). Study of Price and Income Effects on Proportion of Household Food Expenditures (Complete Linear Demand Model Approach). In: Prosiding Seminar Nasional Statistika Universitas Diponegoro (pp. 123-134).

Wardis, G. (2014). Socio-economic factors that have influenced the decline of sago consumption in small islands: a case in rural Maluku, Indonesia. South Pacific Studies, 34(2), 99-116.

Wibowo, A. D., Moeis, A. O., Wiguna, C. B., \& Chaulan, T. A. C. (2015). Policy model of production and price of rice in Kalimantan Selatan. Agriculture and Agricultural Science Procedia, 3, 266-273.

Wibowo, A. D., Moeis, A. O., Wiguna, C. B., \& Chaulan, T. A. C. (2015). Policy model of production and price of rice in Kalimantan Selatan. Agriculture and Agricultural Science Procedia, 3(2015), 266-273.

Wong, J., \& Huang, Y. (2012). China's food security and its global implications. China: An International Journal, 10(1), 113-124.

Wulandari, D., Witjaksono, M., Soseco, T., \& Narmaditya, B. S. (2017). The Development of Productive Economy Cluster through Siparti 3-S and Triple Helix in Kabupaten Lumajang, Indonesia. International Journal of Economics and Financial Issues, 7(2), 25-31. https://www.econjournals.com/index.php/ ijefi/article/view/3796/pdf 